\title{
THE ROLE OF MULTILINGUALISM IN INFLUENCING STUDENTS' ENGLISH LANGUAGE ACQUISITION IN AN OUTSKIRT MALAYSIAN PRIMARY SCHOOL
}

\author{
Siti Norain Duka ${ }^{1}$ \\ Sekolah Kebangsaan Nanga Tada, Malaysia \\ (Email: happyrainbowday@gmail.com) \\ Azlina Abdul Aziz ${ }^{2}$ \\ Faculty of Education, \\ Universiti Kebangsaan Malaysia (UKM), Malaysia \\ (Email: azlina1@ukm.edu.my)
}

Accepted date: 16-03-2019

Published date: 11-07-2019

To cite this document: Duka, S. N., \& Aziz, A. A. (2019). The Role of Multilingualism in Influencing Students' English Language Acquisition in An Outskirt Malaysian Primary School. International Journal of Humanities, Philosophy and Language, 2(6), 97-110.

DOI: $10.35631 /$ ijhpl.26009

\begin{abstract}
Malaysia, as a multilingual country, sets a platform for language learning. Bahasa Malaysia is a language for national unity and English is the second language and other languages as the third language. A child may speak a native language at home, speak the local national language at school and also learn at least a foreign language. The fluency of our second or third language may not be as fluent as the first language. As a result, many studies have been conducted about the learners' mother tongue and the code-switching process. However, a study for the English teachers to overcome the influence of the mother tongue in the Iban community towards their spoken English has not been located. Therefore, a qualitative case study has been conducted in order to provide the description of case-related individuals' and give deeper understanding on the 1) multilingual learners' perceptions toward their English spoken language, 2) exploring multilingual influences in their spoken English and 3) To examine the influence of other languages (Bahasa Malaysia and Iban language) towards English. The participants identified are Ibans from Year 3 primary students; that is located at the outskirt primary school in Kanowit in which they are learning standard Iban language, Bahasa Malaysia and English language at school. Data were collected via semi-structured interviews, and field notes (i.e. classroom observation). The findings were structured into themes: the frequency in communicating the three languages among the three pupils at school in a day, home language support in learning, peers' influence in communicating the English language, learners' effort towards learning English and the mental process in learning language.
\end{abstract}

Keywords: Multilingual, Spoken English, Iban Language, Bahasa Malaysia, Native Language or Mother Tongue, Code-Switching 


\section{Introduction}

All Malaysian citizens have to learn Bahasa Malaysia as a symbol of unity and means of communication among various races in Malaysia after Malaysia's independence. The implementation of Bahasa Malaysia and English in schools have a very large impact on the Ibans, whereby the Ibans can speak Bahasa Malaysia and English other than speaking in their own mother tongue. Somehow, the patterns of the communication and language use among Ibans are changing because of the influence from Bahasa Malaysia and English. Therefore, during the conversation, they tend to mix words from those languages. This study focuses on the code-switching phenomenon among Ibans pupils. Malaysia is a progressing country that consists of Peninsular Malaysia, which is part of Southeast Asian mainland, and the East Malaysia, which are Sabah and Sarawak and together with Labuan Island, that located are on the Borneo Island. Maya, Kuang and Dealwis (2018) mentioned that an estimated population of 31 million comprises 50\% Malays, 25\% Chinese, 10\% Indian and 15\% indigenous people that are mostly from Sabah and Sarawak. As a multi-ethnic multicultural country, Malaysia sets a platform for language learning. According to Hays (2013), he mentioned that there are many languages in Malaysia which are Bahasa Malaysia (official), English, Chinese (Cantonese, Mandarin, Hokkien, Hakka, Hainan, Foochow), Tamil, Telugu, Malayalam, Panjabi, Thai. In Eastern Malaysia on Borneo, several indigenous languages are spoken, but Iban and Kadazan are the most prominent. Maya Khemlani, Ching Hei Kuang and Dealwis (2018) also supported Hays quote by stating Malay, English, Mandarin, and Tamil are the principal languages spoken by those in Peninsular Malaysia meanwhile in Sarawak, Malay is the most commonly spoken dialect, however, in Sabah, Malay and English are commonly used especially for the higher social and economic class.

After the British colonisation, a monolingual-oriented national language policy of using Bahasa Malaysia language has been adopted in order to foster national identity and unity. The official national language was chosen too for promoting efficient communication within the society. To address the language issues in Malaysia, there are two legal documents, which are the Federal Constitution of Malaysia in 1957 and the Language Act in 1967. The Federal Constitution of Malaysia in 1957 defined Malay status as national language of Malaysia. The Language Art in 1967 proclaimed Malay as the national language and an official language in Malaysia. In this research, the focus is on individual multilingualism. A child who may speak a native language at home, speak the local national language at school and also learn at least a foreign language. The fluency of our second or third language may not be as fluent as the first language.

Iban is one of the indigenous groups in Sarawak, which is the largest state in Malaysia on the island of Borneo. According to Asmah Haji Omar (2016), about 30\% of the total population that is approximately 2 million in Sarawak are Iban speakers. Sarawak was under British rulers during the pre-Malaysia period. At first, Sarawak state was ruled by the Brooke Dynasty and then, followed by the British colony. The three English rajahs from the Brooke Dynasty were recognised as Rajah Brooke from 1841 until 1946. James Brooke was the founder of Brooke Dynasty when he as the traveller of fortune found out about the rebellion in Brunei against the resigning sultan. Since the Brooke's success in settling down the rebellion, the Sultan Brunei awarded him Sarawak. Even though, Malay was the official language of Sarawak, James Brooke also introduced English as the medium of instruction in schools. In 1946, a slight change in the official stance for native education when Sarawak was a British colony. In 1955, the Iban language was first included especially for the secondary English schools as "Asian language' rubric in the government school curriculum. In 1957, the "Asian language" rubric was changed as Iban language. In the same year, Iban language became a subject for the 
Sarawak Junior Certificate (SKC) under the name as 'Sea Dayak' whereby no standard syllabus or teacher's guide for its teaching.

Before 1963, the Sarawak State Legislative Assembly decided that only Iban children can be taught Iban as in the Sessional Paper No.3 titled "The Curricula and Syllabuses for Junior Schools'. It stated that only the Iban descent was taught Bahasa Iban. The period for teaching was 120 minutes or three periods a week. The syllabus's purpose is that an Iban student: "should be able to use his mother tongue accurately and effectively, even if in the course of his daily work he uses English. An educated man who has lost his fluency in his own mother tongue will find that there is a barrier between him and the older generation, and he will be unable to help his own people fully." (The Full Teaching Syllabus for Junior Secondary Schools, 1964) as cited in Asmah Haji Omar (2016). Language teaching for Iban language was focused on the four skills such as listening, speaking, reading and writing, and language study, appreciation of Iban traditional poems, interpretation of texts and a two-way translation of Iban and English. The Minister of Education approved Iban language as an additional language taught in the new curriculum for the secondary school in Sarawak in December 1986. On 13 May 1987, the Federal Government has allowed Iban to be taught as a primary school subject with a condition whereby at least 15 pupils under the Pupils Own Language (POL) guidelines. The Ministry of Education accepted the teaching of Iban for the lower secondary school in 1988. On 31 December 1997 with the implementation of the Education Act 1996, the Iban language became as POL for primary and secondary level in national schools. The Curriculum Development Division was established to achieve educational matters and the teaching of ethnic languages by Ministry of Education in 1996. In 2001, the publication of textbook began by the Textbook Division of the Department of Education. According to the Rules on National Education Curriculum 1997, the Iban or other ethnic indigenous language is not as an 'additional language subject' in which it means Iban is not a subject on par with other subjects like history, geography etc. but as a POL in Sarawak. Although the Malaysia National Education Blueprint 2013-2025 did not mention the long-term position of Iban, the objective of the Blueprint was 'building an education system that gives children an appreciation for our unique identity as Malaysians' as quoted by the Prime Minister in the Foreword to the Preliminary Report Executive Summary, Malaysian Educational Blueprint. Four roles of English by Coleman (2011) as cited in Mariche Cholakova (2015) which are: English for academic success, English for international employment opportunities, English for international communication, and English for global education (p.37).

Malaysia has various spoken languages and dialects. With the influence of Malaysian Linguistic Diversity as well as the Malaysian demographics, code-switching may occur in the various language for this multilingual and multicultural country. All ethnicities are exposed to the national language, Bahasa Malaysia and English as formally taught in schools. Muhamad Subakir Mohd Yasin (1998) and Gaudart (1987) as cited in Marina Taeng (2008) described that, "Malaysia's language policy since 1969 is a multilingual nation based on the three major ethnic group with Bahasa Malaysia as the sole national language whereby English language is the official language (p.2). Hence, most of the Malaysians could speak more than one language or dialect although they communicate in one-shared code with other races. English language and Bahasa Malaysia are broadly used in formal or informal situation.

\section{Problem Statement}

According to Coluzzi, Riget, \& Xiaomei (2013) as cited in Albury (2017), the non-Malay indigenous majority in Borneo uses various languages such as Bidayuh, Iban, and DusunKadazan, but are experiencing a shift to Bahasa Melayu English became a lingua franca 
between ethnic groups in which included Malay during British colonial rule and still use in interethnic communication (Jenkins, Cogo, \& Dewey (2011) as cited in Albury (2017). The problem arise for this research is when pupils' mother tongue which is Iban language and Malay language interfere with English spoken language in which they tend to code-switch into other languages than their spoken English.

\section{Research Objectives}

a. $\quad$ To find out pupils' perceptions toward their English spoken language.

b. To investigate the influence of multilingualism on Year 3 pupils' spoken English.

c. To examine the influence of other languages (Bahasa Malaysia and Iban language) towards English.

\section{Research Questions}

a. What is the Year 3 pupils' perceptions toward their English spoken language?

b. Does multilingualism influence year 3 pupils' spoken English?

\section{Literature Review}

\section{Multilingualism}

Multilingualism is defined by Hoffman (1991) as cited in Hamza and Naif (2012) as a multitude of situations where two or more languages are in contact with each other either individually, socially or across nations. Pia Resnik (2018) has conducted a study on multilinguals' use of the first language (L1) and the second language (L2) acquisition inner speech. The participants were $167 \mathrm{bi} /$ multilinguals that were mostly highly proficient users of English. If frequently and proficiently used, the inner speech from L1 could shift into L2 which is English if in the L2 environment, the bi-/multilingual experiences naturalistic exposure to English.

Connie Lam James (2016) study on the multilingual learners in experiencing their multilingual identities in a first-year academic literacy class (ALC) shows that multilingual students' linguistic perceptions and practices were reflective and may be constrained by the dominant linguistic discourses.

Mariche Cholakova (2015) study the influence of English language in a multilingual, multicultural, and multi-ethnic country and a monolingual environment in Macedonia in the Southeast Europe. The discussion was on the positive and negative English influence and the participants' attitudes in a multilingual vs monolingual environment. The role of English based on the literature review became the main obligatory subject as a native language, as a second language or a foreign language. The result in a questionnaire discovered that inside the classroom, the usage of English was mostly noticeable among the students themselves and between the teacher and the students whereby the multilingual environment is more encouraged and practiced rather than in the monolingual environment. Thus, in a multilingual and a multicultural setting has higher usage of English in which the students use English as their medium of communication compared in a monolingual setting that only communicate in English. The results are nearly anticipated with past studies in the literature review in which reported that English are given multiple roles outside of the classroom such as language that dominates technology, for business conferences, job requirements, etc. The results indicated the participants from the monolingual setting never use English in their daily conversation. In a multilingual setting, they use English to communicate especially when addressing to their teachers unlike in a monolingual setting whereby emphasised on the usage of their mother tongue. 
How Soo Ting et. al (2015) studied on the language vitality of Malaysian Languages, particularly on the use of Bahasa Malaysia for national unity and English as the second language, and its relation to identity. Questionnaires were distributed to five primary Malaysian students from vernacular Tamil and Chinese schools to gauge the vitality of these two languages. The findings indicate Bahasa Malaysia and English do not have high vitality but the vernacular languages have high vitality.

Taw Azu (2013) studied on the impact of multilingualism and multiculturalism on English Language Education at Arunanchal Pradesh state that have twenty-five major tribes, sixty dialects and two languages i.e. Boti and Thai. In the finding, the impact of multilingualism on English education was shown in phonological influence of mother tongues of different speech communities, for spoken and written form.

Hamza Akshenqeeti and Naif Alsaedi (2012) conducted a study on the effects of multilingualism and linguistic diversity at societal level from various factors of social life such as education, economy, employment and language policy using a thematic review. The finding showed that the themes are: 1) Multilingualism and education, 2) Multilingualism and employment, 3) Multilingualism and economy, 4) Multilingualism and language policy, 5) Multilingualism and multiculturalism, and 6) Multilingualism and diglossia. This study concludes that the factor that contributed to language-related problems in multilingual societies are due to language and language education policies applied by the government concerned.

Lee Su Kim et. al (2010) conducted a doctoral study of the English language and its impact on identities of multilingual Malaysian Undergraduates. The findings showed that uncommon themes occurred among Malaysian undergraduates that knowledge of English includes their identity negotiations which are 1) Multilingualism with English emerging as the dominant language, 2) English viewed as a pragmatic language and a language of empowerment, and 3) Varying degrees of 'othering'.

\section{Code-Switching}

Gumpers (1964) as cited in Amara Yeoh Jo Ann (2017) defined the term "code-switching" whereby "code" means language or language variety while "switching" means an exchange in the use of at least two languages.

Malini Devi Paramesvaran and Jia Wei Lim (2018) studied the code-switching practices in Malaysian multilingual primary classroom from the teacher and students' perspectives. The finding revealed that teacher's codeswitching practices helped clear the students' doubts, reinforced their learning, and encouraged student participation in English lessons. Similar perspective on code-switching gained from teacher and one of the participants. However, another two participants felt code-switching helped during teacher's explanations especially in constructing simple sentences. The study concluded not all students depend on codeswitching in the English lessons.

Amara Yeoh Jo Ann (2017) explored on the rural teachers' usage of code-switching in a rural school in Pahang and also on the teachers' and weak students' perspectives. The findings showed that teachers used code-switching for a comprehension strategy during teaching in order to explain vocabulary, concepts and sentences so that could support the low proficiency students and the difficulty of the text learned in the class. 
Tandoc (2016) studied on students' perception towards code-switching in an ESL classroom. The finding shows that the participants regardless of their profile have positive perception on the use of codeswitching in their classes which act as an instructional strategy of learning and effective communication between students and the instructor.

Joanna Tiffany Selamat (2014) studied code-switching in the Malaysian ESL classrooms. The participants are ten teachers and sixty students from two secondary schools in Tenom, Malaysia. Data from questionnaires, semi-structured interviews and classroom observations were collected. The classroom observation analysis indicated both teachers and students use codeswitching for many purposes in the ESL classroom. Teachers used code-switching to facilitate students' comprehension and knowledge of target language grammar and also reduce learners' learning anxieties. Students used code-switching for learning strategy in order to reduce their limited competence in the target language.

Paramasivam Muthusamy (2010) studied a sociolinguistic study on codeswitching in communication of Malaysian secondary school students. The settings are from four secondary schools in Klang Valley in which one school from an urban setting, two from suburban, and one from a rural area. Twenty sample were obtained in which twelve were Indian students, four Malays, and four Chinese. The participants were given two topics. The findings show that codeswitching during conversation that happened from Bahasa Melayu to English, Tamil or Chinese to English or vice versa is more habitual by nature.

\section{Language Acquisition Versus Learning}

Acquisition occurs when it happened naturally and gradually developing language through interaction to those that know the target language. Learning a language usually occurs formally like in school when having more conscious decision in order to store the knowledge of the target language. Learners' speed in learning or language acquisition depends on the ability of the learners and the environment the learners live. Language environment involved everything around the learners that include both audible and visible.

The first language acquisition is the language that the child speaks first. Holmes (2001) explained a typical family interaction would demand home as the setting whereby there would be family members and family activities. L1 usually linked with the 'Grammar Translation Method' in L2 teaching methods such as the Direct Method, Audiolingual Method and Communicative Language Teaching (Ellis \& Shintani 2014; Richards \& Rodgers 2014 \& Spada 2007) as cited in Amara Yeoh Jo Ann (2017). Grammar Translation Method emphasised on memorising grammatical rules, L1 use, and text translation. The Direct Method uses only L2 for communication and meaning-making through demonstration and visual aids. The Audiolingual Method related with Skinner's behaviourist psychology that drills of L2 grammatical sentence patterns to teach the language. Communicative Language Teaching (CLT) is purposely for communication competence.

As for the second language acquisition (L2), Krashen (1982) mentioned that there are three methods in the second language instruction which are the Direct Methods, the Audiolingual Method and the Communicative Language Teaching (CLT) would give input by maximising the learner's exposure to authentic target language forms and structures by removing the L1 from the ESL classroom. To have successful language acquisition, Krashen's comprehensible input hypothesis retains the maximum exposure of the target language structures. 
Jorda (2005) had compared between the third language acquisition (L3) with the second language acquisition (L2) in which L3 is non-linear whereby L2 is linear for the language learning. Jorda (2005) as cited in Maureen Lugoloobi-Nalunga (2013) clarified that between L2 and L3 learning have differences. The differences in attributing distinctive characteristics for L3 development are: 1) non-linearity, 2) maintenance, 3) individual variety or idiosyncrasy, and 4) interdependency and quality change. This means in L3 there are variety of ways for the learners to pick up skills when learning a language.

\section{Methodology}

The research design used is qualitative case study. According to Cohen, Manion and Morrison (2007) as cited in Amara Yeoh Jo Ann (2017), case studies involve studying a "bounded system" or "phenomena" such as a school, community, organisation, and unique situations. Therefore, in this research, the phenomenon that being studied is the influence of multilingualism in spoken ESL classroom and bounded system is an outskirt primary school in Kanowit.

\section{Research Site}

This study was conducted in SK Nanga Tada, in the Kanowit district of Sarawak along the Sungai Rajang river. SK Nanga Tada is an outskirt national primary school. Majority of the students are Ibans. Therefore, the common language use by students is Iban language. However, in school too, the students are learning standard Iban language, Bahasa Malaysia and English.

\section{Research Participants}

3 out of 22 pupils in Year 3 Cerdik were chosen. The participants are identified based on their top scores in English examination. This indicates that the participants are either proficient or average proficiency in English. The names of the participants will be changed to pseudonyms. This is to protect their privacy and confidentiality.

Table 1: The research participants' details

\begin{tabular}{|c|c|c|c|c|c|}
\hline NO. & $\begin{array}{c}\text { THE NAME OF } \\
\text { RESEARCH } \\
\text { PARTICIPANTS }\end{array}$ & SEX & $\begin{array}{c}\text { CLASS } \\
\text { OBSERVED }\end{array}$ & STUDENTS' L1 & $\begin{array}{c}\text { STUDENTS' } \\
\text { PROFICIENCY }\end{array}$ \\
\hline 1. & PUPIL B & FEMALE & 3 CERDIK & IBAN LANGUAGE & GOOD \\
\hline 2. & PUPIL D & FEMALE & 3 CERDIK & IBAN LANGUAGE & AVERAGE \\
\hline 3. & PUPIL E & MALE & 3 CERDIK & IBAN LANGUAGE & AVERAGE \\
\hline
\end{tabular}

\section{Data Collection Methods}

\section{Classroom Observation (Field Notes)}

I observed during the lesson period over a period of two weeks. The classes started with introduction to the topics and the objectives of the lesson. Classroom observation allows me to study the learning processes in a natural setting while giving evidences with more detailed and precise compared to other instruments. I was both a participant and non-participant observer. A non-participant observer is a researcher who does not get involved in the participants' activities. I sat at the corner in front of the class so that I could easily view all my students. Sometimes I would walk around the class when they had discussion or given a demonstration. This enabled me to observe students' interactions and follow their discussions. I would 
participate in some of the activities and discussion when students sometimes worked in groups. Participant observation allowed me to experience my own teaching activities myself. I could clarify them my observations by asking questions. I took field notes so that I could remember the processing information.

\section{Semi-Structured Interviews}

Face to face interview was conducted in order to make the participants to feel comfortable. I asked questions to one participant at a time and record their answers. They are given pseudonyms to protect their identities. I believe that the participants would feel more comfortable to give their own perspectives personally as the confidentiality is guaranteed rather than a focus-group interview whereby the participant's views are shared with others. Semistructured interviews allow me to probe deeper and clarify my interpretation since any relevant issues may arise mid-interview. This has allowed me to categorise the responses obtained for the important themes. The interview questions were given to each participant in which the questions were in multilingual. The reason of multilingual version questions in the interview questions is to allow the participants understand the questions better. All the questions were open-ended as I wanted to gain the participants' feedback in their own words and original opinions. This would allow the participants to answer without presented or implied choices through feedback in their own voice of views, perceptions and experiences.

\section{Ethics Issues}

Ethical issues are very important when wanted to conduct the research. Some considerations that involved the research participants must obtain 'informed consent', protecting participants 'privacy and confidentiality', ensuring that procedures do not cause any 'harm' to participants and avoiding 'deception' that may deceive participants (Tracy, 2012, p. 243) as cited in Selamat (2014). (p.51). I obtained approval from the participants that I selected. The multilingual learners were informed that their participation was entirely voluntary, and they could withdraw at any point during the research or interview if they did not feel comfortable.

\section{Findings}

The findings gathered from semi-structured interviews and field notes. All the participants were interviewed and observed to gather in-depth perspectives. The findings from this research will be synthesised and discussed according to themes.

\section{Findings From Structured Interviews}

\section{Theme One: Home Language Support In Communicating The English Language.}

\section{Question 2 - Which Language Do You Speak At Home?}

Pupil B's response:

Aku bekomunikasyen ngena jaku Iban (Bahasa Iban)

I spoke in Iban language and Bahasa Malaysia. (English version)

Pupil D's response:

Aku bekomunikasyen ngena jaku iban enggau jaku melayu. (Bahasa Iban)

I spoke in Iban language and Bahasa Malaysia. (English version)

Pupil E's response:

Aku bekomunikasyen ngena jaku iban enggau jaku melayu. (Bahasa Iban)

I spoke in Iban language and Bahasa Malaysia. (English version) 
Pupil B's response:

Question 3 - Have You Ever Spoken English At Home? Why?

Aku kala bekomunikasyen ngena jaku Inggeris enggau akak aku. Mayuh bup jaaku Inggeris akak dipinjau aku (Bahasa Iban)

I had spoken in English with my sister. My sister taught me English at home. Many

English story books that she owned that I borrowed at home. (English version)

Pupil D's response:

Enda. Laban semua bakih aku bekomunikasyen ngena jaku Iban. Aku berandau enggau indai pan ngena Jaku bansa kitai. (Bahasa Iban)

No because all my friends speak in Iban. I speak with my mum in Iban too. Iban

language is my own language. (English version)

Pupil E's response:

Enda, tapi indai ku selalu meri latih dalam jaku inggeris. (Bahasa Iban)

No but my mother gave me English exercises for me to do. (English version)

\section{Theme Two: Peers' Influence In Communicating The English Language}

\section{Question 6 - When You Talk To Your Friends, Which Language Would You Prefer? Bahasa Iban, Bahasa Malaysia Or English? Why?}

Pupil B's response:

Jaku Iban laban mayuh bakih aku bekomunikasyen ngena jaku iban. Sida enda mereti enti aku bejaku ngena jaku Inggeris. (Bahasa Iban)

Iban language since most of my friends speak in Iban language. They did not understand if I speak to them in English. When I taught my friends that weak in English, they understand better if I used Iban language. (English version)

Pupil D's response:

Aku nguji bejaku ngena jaku inggeris tajapan aku enda tentu landik. Kala mega aku bekomunikasyen dalam jaku iban laban nya lenih midsh dipelajarka. (Bahasa Iban)

I keep trying to speak in English although I know I am not good in speaking skill.

There are times when I speak in Iban language since most of my friends could speak fluently in Iban language than Bahasa Malaysia or English. (English version)

Pupil E's response:

Kadang-kadang kami bekomunikasyen ngena jaku iban laban mayuh agi bakih aku bansa iban lalu landik agi bekomunikasyen ngena jaku iban. (Bahasa Iban) Sometimes I speak in Bahasa Malaysia. Sometimes in Bahasa Iban since many of my friends could speak fluently in Iban language than Bahasa Malaysia or Bahasa Inggeris. (English version)

Question 7 - Do You Prefer To Speak With Your Friends In English Or Bahasa Iban Or Bahasa Malaysia When You Have Discussion During Your English Lesson?

Pupil B's response:

Aku bejaku ngena jaku bukai kelimpah ari jaku bukai. (Bahasa Iban)

Mix. If I do not know the words I discuss in Iban or in Bahasa Malaysia. (English

version)

Pupil D's response:

Kami bekolaborasyen ngena jaku inggeris tang kala mega ngena jaku bukai. (Bahasa Iban)

I discuss with my friends in English but mix with other language. (English version) 
Pupil E's response:

Lebuh maya belajar enggau bala bakih aku selalu nguji deka bekomunikasyen ngena jaku inggeris. Enti sema bisi pekara ends ditemu kami betanya ngagai pengajar. (Bahasa Iban)

If in discussion with friends, I tried to speak in English language. If I did not know, I will ask teacher or discuss with friends in Iban. (English version)

In the semi-structured interview, the selected transcriptions of all the participants clearly shows the theme on the home language support in communicating the English language and peers' influence in communicating the English language. The findings show that in question 2, all of the participants communicated using Bahasa Malaysia and Bahasa Iban at home. Furthermore, most of their friends are highly proficient in Iban language rather than English language or Bahasa Malaysia. All the participants mentioned that because their friends can speak in Iban fluently than other languages, they had to speak in Iban. Pupil B stressed that their friends would not be able to understand if she speaks in English. She also stated that while teaching her friends, using Iban language would help her friend to understand better. Based on the findings, this shows that Iban is probably their mother tongue. The sense of identity was there as mentioned by Pupil D as "Iban language is my own language." Peers' influence has caused them to communicate in Iban language among their friends whereas community and home language acts as the starting point in which their language develops and strengthens as a core. Only the maximum usage of English language through home, peers and community would support their communication in English language.

\section{Theme Three: Learners' Efforts Towards Learning English}

Pupil B's response:

\section{Question 7 - How To You Develop Your English Language?}

Aku rindu macha bup cherita Inggeris baka bup ensera, kereban sains enggau ti bukai. Aku me rindu belagu inggeris. (Bahasa Iban)

I love to read stories in English. There are fairy tales, folktales, sciences and more. I also listened to the English songs. (English version)

Pupil D's response:

Aku rindu meda cherita kartun ti ngena jaku inggeris. Kelimpah ari nya, aku mega rindu mendingka lagu inggeris. (Bahasa Iban)

I like watching English cartoons and listen to the English songs. (English version)

Pupil E's response:

Aku rindu meda cherita katun Bahasa Inggeris enggau Disney movie baka Frozen, Mickey Mouse enggau ke bukai. Aku mendingka randau setiap watak nya enggau manah sereta macha subtitle jaku ke diberi ba baruh. (Bahasa Iban)

I like watching English cartoons and Disney movies such as Frozen, Mickey Mouse and more. I listened attentively to the characters when they spoke in English and read the translation below. (English)

All the participants showed various ways of learning the English language. Pupil B has learnt English through reading. She loves to read the English stories books. A variety of English books that she read were fairy tales, folktales, sciences and more. She also likes to listen to the English songs. As for Pupil D, she preferred to watch English cartoons. However, she also learnt English language by listening to the English songs. The evidence in transcription Pupil B, "I like watching English cartoons and listen to the English songs." 
I believe that songs maybe sound catchy to the learners. This allows it to be easily remembered by the learners. Besides that, songs usually use the element of repetitions and drilling. This will help the learners to recall certain words in the song lyrics and also help them to have better pronunciation if the song is in British English. Pupil E also like to watch English cartoons and English movies. He mentioned that he watched Disney movies such as Frozen, Mickey Mouse and more. This was clearly described in the transcription of question 8 as he said, "I like watching English cartoons and Disney movies such as Frozen, Mickey Mouse and more. I listened attentively to the characters when they spoke in English and read the translation below."

Identifying the various ways of learning would indeed help the English teachers to know teaching strategies that relevant pertaining to the multilingual students.

\section{Theme Four: The Mental Process Of The Language Learning}

\section{Question 9 - Do You Think Using Other Languages Would Affect Your English Results? Why?}

\section{Findings From The Semi-Structured Interview And The Reflective Field Notes}

Pupil D's response:

Aku ngena jam ti lama agi dikena nyaut tanya ba tikas tinggi. Laban pia jaku inggeris ukai jaku ti selalu dikena aku bekomunikasyen. (Bahasa Iban)

Yes, I have to think longer to answer questions that I did not understand in English. I think because English is not my main language. (English version)

Pupil E's response:

Kadang aku ngasai tusah ka berunding dalam jaku iban enggau jaku Melayu, nyadi aku pan nukar leka jaku nya ngagai Bahasa Inggeris. (Bahasa Iban)

There were times when I felt difficult to think in Bahasa Iban or Bahasa Malaysia and then, I have to change the words in English. (English version)

In the semi-structured interview in question 9, two out of three participants' responses did show that the mental process may lead to code-switching. One of them think that learning English is difficult as they have to take the time to think consciously before they could give the appropriate responses. The reason that leads her to think longer is because of English is not her native language. This was mentioned by Pupil D, "Yes, I have to think longer to answer questions that I did not understand in English. I think because English is not my main language." As for Pupil E, he had to change the words in English if he cannot think in Bahasa Iban or Bahasa Malaysia.

\section{Artifact 1 Reflective Field Note}

Since Pupil E sits close to Pupil D, I overheard their conversation while I facilitated their learning. Pupil E asked Pupil D in Iban language, "Bakani ka ngaga tu?" Pupil D replied to him, "Tulis jawapan ti betul. Tulis jawapan ti salah." In English translation means, "How to do this?" "Write 'True' for the correct statement and write 'False' for the incorrect statement." (Field Note, $2^{\text {nd }}$ July 2018)

\section{Artifact 2 Reflective Field Note}

Pupil A tried to clarify with me for the lesson instructions. She asked me in Bahasa Malaysia. She said, "Ini gunting kah, Miss? Are these scissors? (Field Note, $27^{\text {th }}$ July 2018) 
In the reflective field note, I became the participant observer. I observed how the participants code-switched or rather choose other languages than English in order to interact and communicate the spoken language. I wrote down how the participants interacted with other students during the group discussion. Pupil E, who was one of the participants, asked Pupil D in Iban language. He said, "Bakani ka ngaga tu?". In English translation means, "How to do this?" Pupil D replied, "Tulis jawapan ti betul. Tulis jawapan ti salah." In English translation it means, "Write 'True' for the correct statement and write 'False' for the incorrect statement." (Refer to field note, Field Note, 2nd July 2018.) Pupil B clarified to her teacher about the instruction given using Bahasa Malaysia instead of English. She asked, "Ini gunting kah, miss?" Are these scissors? (Refer to field note, Field Note, 27th July 2018.)

However, these findings did not indicate how communicating in the English language affects the participants' test paper results as English test paper was not only on speaking skill but also comprised of various skills such as reading, writing and listening.

\section{Discussion}

The analyses of the result have shown that multilingualism does influence learners in acquiring English language. English is not their dominant language. However, based on the findings, the students' acquisition in English language was highly influenced from their home learning support. The respondents have a good attitude and motivation in learning English language even though English language is not their dominant language nor within the society's context. Therefore, Bahasa Malaysia was thought to be the second choice while English is the last choice since English is highly recognised as an international language in which it is important in international standing.

\section{Implication}

Based on the findings and the discussion, this section provides implication of the research. The purpose of this study is to find out the influence of multilingualism towards pupils' spoken English. This study provides description of case-related individuals' in which the participants are selectively selected. This study provides deeper understanding on multilingual learners' perceptions toward their English spoken language and exploring multilingual influences in their spoken English. Some of the issues highlighted in the findings are much related to the learners' perceptions in acquiring English, how language gave identity to them, their positive attitudes and intrinsic motivation that are influenced from their surrounding such as home, peers and community. To further develop their English language acquisition, the learners have to be proactive such as employing varied ways of learning. Based on their interviews, they reported they had the support from their parents and siblings that made them be good English learners. Their willingness to try to speak the English language also become another contributing factor.

Based on the findings, the multilingual learners struggle to learn English because of several issues. The first issue is the language learning circle among self, peers and community. The choice of language spoken by their community and peers especially had influenced the multilingual learners to use their mother tongue to communicate and interact since most of the community is Ibans.

All of these need to be considered as contributing factors for the success of learning English among multilingual learners. It is hoped that the findings could help English teachers to have better teaching practise as they try to understand the influence of multilingualism in learning the English language. 


\section{Conclusion}

The findings from this research indicate that the learning of English is influenced by the environment and culture multilingual learners are situated in whereby their parents or siblings, peers' attitude and also their community support their acquisition of English. The peers rather use Iban language or Bahasa Malaysia as their medium of communication. Thus, this influenced the research participants choice of language during the discussion. The multilingual learners also code-switched when one of them tried to fill-in-the blanks in Bahasa Malaysia and Iban language although the test was meant for English.

From the participants' perspectives, it was found that they found difficulty in using or thinking in English. Therefore, they had to mix the language. This happened also to the good learners since sometimes, they tend to use other languages to express themselves in order to get their message across. Despite the occurrence of code-switching, the multilingual learners whom were highly proficient in English made their own effort to progress in the English language.

\section{References}

Albury, N. J. (2017). Mother tongues and languaging in Malaysia: Critical linguistics under critical examination. Language in Society, 46(4), 1-23.

Amara Yeoh Jo Ann. (2017). Exploring teacher's code-switching into L1 for teaching weak learners in a rural Malaysian secondary school. Master of TESL. University Kebangsaan Malaysia.

Asmah Haji Omar (2016). Languages in the Malaysian education system. Third Avenue, New York, NY: Routledge.

Azu, T. (2013). Impact of multilingualism and multiculturalism on English language education: The case of Arunachal Pradesh, India. Mediterranean Journal of Social Sciences, 4(11), 665-670.

Cavendish, L. M. (2011). Stories of international teachers: A narrative inquiry about culturally responsive teaching. $\mathrm{PhD}$ (Doctor of Philosophy) thesis. University of Lowa.

Cholakova, M. (2015). The influence of the English language in a Multilingual and a monolingual environment: A comparative approach. International Journal of English Language Teaching, 3(4), 35-78.

Ermela, B. (2017). Effects of early multilingualism on child development and implications for primary education. Bachelor thesis. University of Oulu.

Hamza Alshenqeeti \& Naif Alsaedi. (2012). Is multilingualism a problem? The effects of multilingualism at the societal level. ARECLS, 9(1), 63-84.

How, Soo Ying, Chan, Swee Heng \& Ain Nadzimah Abdullah. (2015). Language vitality of Malaysian languages and its relation to identity. GEMA Online Journal of Language Studies, 15(2), 119-136.

James, C. L. (2016). Multilingual learners: Student experiences in a first-year academic literacy class. Degree of Master of Arts. Simon Fraser University.

Khairul Aini Mohamed Jiri. (2014). Becoming teachers of English-language learners in two multicultural countries: Narratives from preservice teachers in the United States and Malaysia. Degree of Doctor of Philosophy. The Pennsylvania State University.

King, J. R. \& Chetty, R. (2014). Codeswitching: linguistic and literacy understanding of teaching dilemmas in multilingual classrooms. Linguistics and Education, 40-50. http://dx.doi.org/10.1016/j.linged.2013.12.002.

Lee, Su Kim, Lee, King Siong, Wong, Fook Fei \& Azizah Ya'acob. (2010). The English language and its impact on identities of multilingual Malaysian undergraduates. GEMA Online Journal of Language Studies, 10(1), 87-101. 
Muthusamy, P. (2010). Codeswitching in communication: A Sociolinguistic Study of Malaysian Secondary School Students. Pertanika Journal of Social Sciences \& Humanities, 18 (2), 407-415.

Norsimah Mat Awal, Mohammad Fadzeli Jaafar, Mohammed Azlan Mis \& Hayati Lateh. (2013). Maintenance of mother tongue: Patterns of language choice at the MalaysianThai border. Procedia - Social and Behavioral Sciences, 118, 282-287. doi: 10.1016/j.sbspro.2014.02.038.

Resnik, P. (2018). Multilinguals' use of L1 and L2 inner speech. International Journal of Bilingual Education and Bilingualism: 1-19.

Selamat, J. T. (2014). Code Switching in the Malaysian ESL Classroom. Master of Arts Thesis. University of Otago.

Tandoc, J. P. (2016). Code-Switching in an ESL Classroom. Imperial Journal of Interdisciplinary Research (IJIR), 2(7): 651-656. 